\title{
LIM Domain-Binding Protein 2
}

National Cancer Institute

\section{Source}

National Cancer Institute. LIM Domain-Binding Protein 2. NCI Thesaurus. Code C105936.

LIM domain-binding protein 2 ( $373 \mathrm{aa}, \sim 43 \mathrm{kDa}$ ) is encoded by the human LDB2 gene.

This protein is involved in transcription factor regulation. 